\title{
RESEARCH
}

\section{Characterization of the Mouse Histone Gene Cluster on Chromosome 13: 45 Histone Genes in Three Patches Spread over $1 \mathrm{Mb}$}

\author{
Zeng-Feng Wang, ${ }^{1}$ Tatiana Krasikov, ${ }^{1}$ Mark R. Frey, ${ }^{4}$ Jean Wang, ${ }^{1}$ \\ A. Gregory Matera, ${ }^{4,5}$ and William F. Marzluff ${ }^{1-3,6}$
}

\begin{abstract}
${ }^{1}$ Department of Biology, ${ }^{2}$ Department of Biochemistry and Biophysics, and ${ }^{3}$ Program in Molecular Biology and Biotechnology, University of North Carolina at Chapel Hill, Chapel Hill, North Carolina 27599-7100; ${ }^{4}$ Department of Genetics and ${ }^{5}$ Center for Human Genetics, Case Western Reserve University School of Medicine and University Hospitals of Cleveland, Cleveland, Ohio 44106-4955
\end{abstract}

The histone gene cluster on mouse chromosome 13 has been isolated and characterized. Using overlapping YAC clones containing histone genes from chromosome 13 , a contig of $\sim 2 \mathrm{Mb}$ has been defined. It contains 45 histone genes, organized in three patches containing tightly clustered genes. An 80-kb patch (patch III) containing 12 histone genes is near one end of the contig, and a similar-sized patch (patch I) containing 15 histone genes is near the other end of the contig, located at least $500 \mathrm{~kb}$ from the central patch (patch II) of histone genes. The entire cluster contains six histone $\mathrm{Hl}$ genes, including the testis-specific histone Hlt gene that maps to the middle of the cluster. All nine histone $\mathrm{H} 3$ genes in this cluster have been sequenced, and their level of expression determined. Each histone $\mathrm{H} 3$ gene is distinct, with five genes encoding the $\mathrm{H} 3.2$ protein subtype and four genes encoding the H3.l protein. They are all expressed, with each histone $\mathrm{H} 3$ gene accounting for a small proportion of the total histone $\mathrm{H} 3 \mathrm{mRNA}$.

There are five classes of histone proteins that together package the DNA of eukaryotes into chromatin (Kornberg 1977). The four core histones, $\mathrm{H} 2 \mathrm{a}, \mathrm{H} 2 \mathrm{~b}, \mathrm{H} 3$, and $\mathrm{H} 4$ make up the octamer of the nucleosome core, while the fifth histone, histone $\mathrm{H} 1$, binds to the linker DNA and directs the higher order packing of chromatin. Most of the histone genes are expressed in a replicationdependent manner, being expressed only during $S$ phase when DNA is being synthesized. The replication-dependent histone genes are distinct from other metazoan genes, because they encode nonpolyadenylated mRNAs and lack introns (Marzluff 1992). The replication-dependent histone mRNAs end in a highly conserved 26nucleotide sequence that can form a stem-loop (Birnstiel et al. 1985; Marzluff 1992). The 3' ends are formed by a cleavage reaction that requires U7 snRNP, which binds to a purine-rich sequence 3 ' of the stem-loop (Gick et al. 1986; Mowry and Steitz 1987; Soldati and Schümperli 1988).

Each class of histone proteins, with the ex-

${ }^{6}$ Corresponding author.

E-MAll marzluff@med.unc.edu; FAX (919) 966-6821. ception of histone $\mathrm{H} 4$, consists of a number of nonallelic variants that differ from one another in only a few amino acids (Zweidler 1984). For example, there are three histone $\mathrm{H} 3$ proteins, histones H3.1, H3.2, and H3.3. The histone H3.1 and $\mathrm{H} 3.2$ proteins are replication dependent, whereas the histone $\mathrm{H} 3.3$ protein is synthesized constitutively (Wu and Bonner 1981) from a gene not linked with the replication-dependent histone genes, which contains introns and encodes a polyadenylated mRNA (Brush et al. 1985; Wells and Kedes 1985). There are also multiple histone H2b and H2a proteins (Zweidler 1984), although their complexity is not yet completely understood. There are seven types of histone $\mathrm{H} 1$ proteins in mammals, which differ from one another extensively in both the amino and carboxyl terminus while sharing a highly conserved core region (Parseghian et al. 1994). Whether any of these histone variants have distinct functions is not known.

The histone genes in mammals are located on two chromosomes, chromosomes 1 and 6 in human (Triputti et al. 1986; Allen et al. 1991), and chromosomes 3 and 13 in mouse (Graves et 


\section{MOUSE HISTONE GENE CLUSTER ON CHROMOSOME 13}

al. 1985). Most of the histone genes in the mouse are located on chromosome 13 (Graves et al. 1985). We report here the molecular characterization and cytogenetic localization of the histone gene cluster on mouse chromosome 13 . About 45 histone genes, including all 5 replication-dependent histone $\mathrm{H} 1$ genes and the testisspecific histone H1t gene, are located in this cluster. Included in this cluster are nine functional histone $\mathrm{H} 3$ genes that are each expressed in similar amounts. These genes are not uniformly dispersed throughout the cluster but are found in three patches that each have multiple closely spaced histone genes. These three patches are separated by several hundred kilobases of DNA that do not contain histone genes.

\section{RESULTS}

The five classes of replication-dependent histone genes are encoded by a multigene family, containing 10-20 copies of each of the core histone genes in the mouse (Jacob 1976) and one copy of each of the genes encoding the $\mathrm{H} 1$ histones (Doenecke et al. 1994; Dong et al. 1994). The genes encoding the core histone proteins are tightly linked in all metazoans that have been studied. In mammals there are two clusters of replicationdependent histone genes, located on separate chromosomes: chromosomes 1 and 6 in human (Triputti et al. 1986; Allen et al. 1991) and chromosomes 3 and 13 in mouse (Graves et al. 1985). To understand the overall organization of the histone genes, we undertook the isolation of the entire histone gene cluster. Because the coding regions of these genes have been highly conserved at the nucleic acid level, we used PCR to screen the yeast artificial chromosome (YAC) library with two primers from invariant regions of the histone H3 sequence. Nine independent YAC clones were isolated, and these fell into two distinct groups, each of which contained multiple histone genes.

\section{Characterization of the Histone-containing YACs from Mouse Chromosome 13}

The YACs ranged in size from 250 to $750 \mathrm{~kb}$. Despite the fact that some of the mouse histone genes are present on mouse chromosome 3 (Graves et al. 1985), all nine YACs mapped to mouse chromosome 13 . A schematic of the proposed organization of the seven nonchimeric YAC clones, spanning $-2 \mathrm{Mb}$, is shown in Figure 1 . The deduced overlaps and the approximate po- sition of the histone $\mathrm{H} 3$ and $\mathrm{H} 1$ genes are shown. There are three patches of histone genes, labeled I-III (Fig. 1). Within each patch are tightly linked histone genes, 15 genes in patch I, 18 genes in patch II, and 12 genes in patch III. The evidence for this organization is detailed below.

\section{Nine Histone $\mathrm{H} 3$ and Nine Histone H4 Genes Are Present on the YACs}

For initial characterization of the YACs, Southern blots were done using individual histone genecoding regions as probes. There were nine histone $\mathrm{H} 3$ genes (Fig. 2A) and nine histone $\mathrm{H} 4$ genes (Fig. 2B; Table 1) present on the seven YACs. These YACs fell into two groups based on the histone $\mathrm{H} 3$ and $\mathrm{H} 4$ genes present on the YACs: The first contained YACs D6, ED11, CTC4, and $\mathrm{BC} 11$, and the second contained YACs VB2, XF10, and DE8. YACs XH10 and CID1 were also contained in the first group, although both of these YACs were chimeric and therefore not useful for constructing the map. The first group contained seven histone $\mathrm{H} 3$ and six histone $\mathrm{H} 4$ genes (Fig. 2A,B), in addition to five histone $\mathrm{H} 1$ genes (see below), six histone $\mathrm{H} 2 \mathrm{~b}$, and six histone $\mathrm{H} 2 \mathrm{a}$ genes (data not shown). YACs VB2, XF10, and DE8 formed the second group, and these YACs contained two histone $\mathrm{H} 3$ and three histone $\mathrm{H} 4$ genes (Fig. 2). In addition, this group contained one histone $\mathrm{H} 1$ gene (see below), five histone $\mathrm{H} 2 \mathrm{a}$, and four histone H2b genes (not shown). None of these 15 genes were present in the first group. All of the histone genes detected were present on at least two YACs, allowing us to construct an unambiguous map.

The core histone genes present on each YAC are summarized in Table 1 . The histone $\mathrm{H} 3$ and $\mathrm{H} 4$ genes were lettered A-I, based on their identification by Southern blots (Fig. 2). Several mouse histone $\mathrm{H} 3$ genes from chromosome 13 have been characterized previously by us and others (Sittman et al. 1983b; Taylor et al. 1986; Kosciessa and Doenecke 1989; Gruber et al. 1990; Brown et al. 1996). In the legend to Table 1 we have identified those histone $\mathrm{H} 3$ genes that were previously cloned, assigning each of them to the appropriate gene. Similarly the histone $\mathrm{H} 4$ genes were lettered A-I, and the two previously identified histone $\mathrm{H} 4$ genes from chromosome 13 (Meier et al. 1989; Drabent et al. 1995) are identified in Table 1.

Because several small clusters of histone genes had been cloned previously in $\lambda$ phage, we 
WANG EI AL.

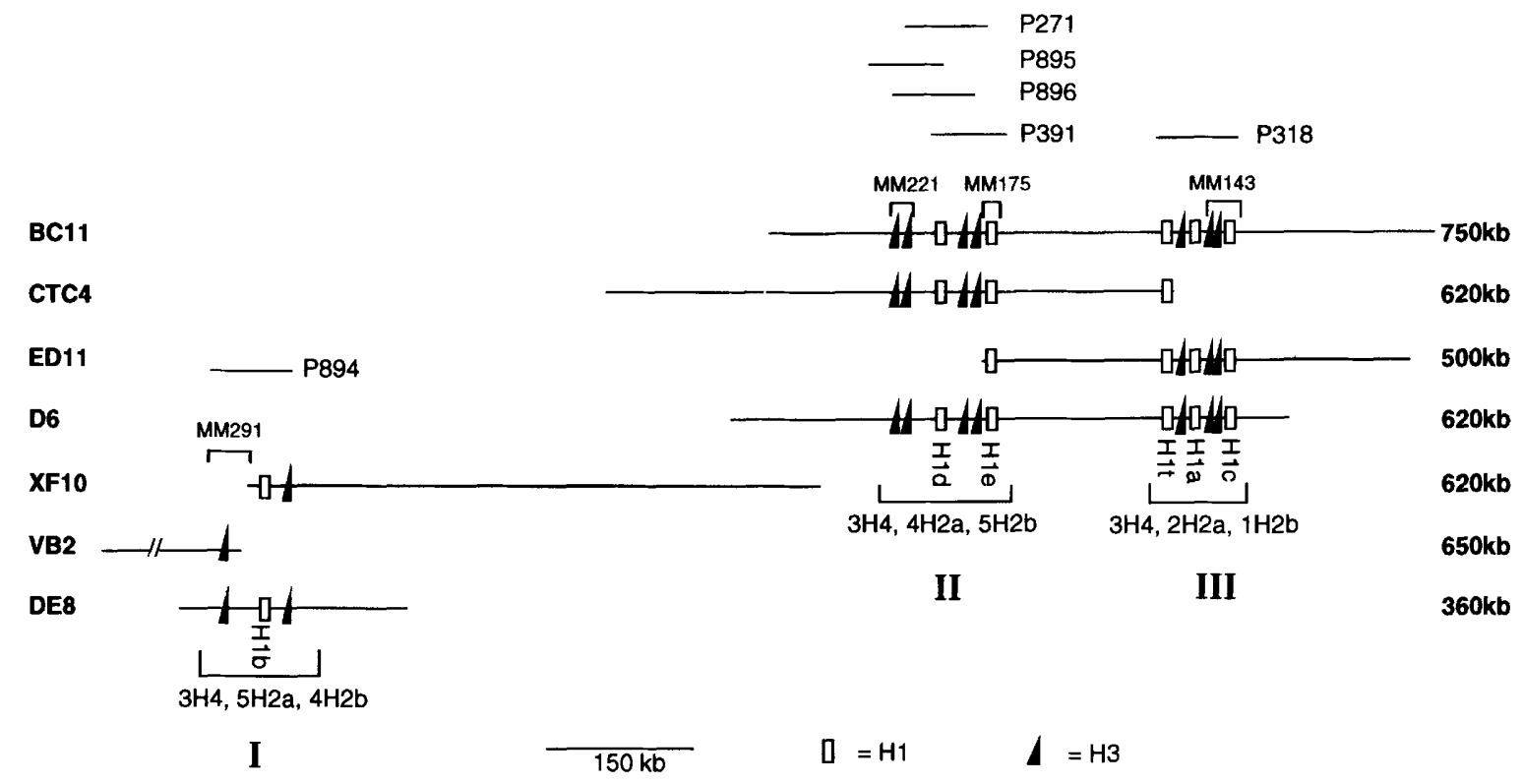

Figure 1 Map of the histone gene cluster on chromosome 13. The seven nonchimeric YACs are aligned showing their size, relative order, and number of histone genes. For simplicity, only the $\mathrm{H} 1$ and $\mathrm{H} 3$ genes are shown on the map, with the number of the other core histone genes indicated beneath the cluster. The locations of the P1 clones and the previously isolated $\lambda$ phage are indicated above the YACs. The three patches are indicated by Roman numerals. The precise distance between the patches is not known.

synthesized primers specific for one of the genes on each phage and screened the YACs for the presence of each of these genes. We located phage MM221 (Sittman et al. 1981), MH53 (Gruber et al. 1990) and the overlapping MM143 phage (Yang et al. 1987), MM291 (Liu et al. 1987), and MM175 (Dong et al. 1994) on multiple YACs, allowing us to designate their location on the proposed map (Fig. 1). We also located the four previously isolated mouse histone $\mathrm{H} 1$ genes (see below), as well as the H2a gene reported by Ekblom and co-workers (Fecker et al. 1990), which was present on YACs VB2 and DE8. All the previously reported replication-dependent histone genes from chromosome 13 are present in these YACs. We have not yet isolated all of the $\mathrm{H} 2 \mathrm{a}, \mathrm{H} 2 \mathrm{~b}$, and $\mathrm{H} 4$ genes identified on these YACs. The other replication-dependent mouse histone genes are present in a smaller cluster on mouse chromosome 3 (Wang et al., this issue).

\section{The Histl Gene Cluster Maps to Mouse Chromosome 13A2-3}

We used fluorescence in situ hybridization to confirm the location of the YAC contig to chromosome 13. The signals showed exclusive localization to chromosome 13 , with the exception of clones XH10 and CID1, which were clearly chimeric. In addition to chromosome 3 , XH10 also hybridized to chromosomes 9 and 17 , whereas CID1 showed additional signals on chromosome 1. Examples of these images are shown in Figure 3A-D. DAPI (G/Q) banding and FLpter measurements (19\%-29\%; Fig. 3E) allow us to localize the Hist1 cluster to the A2-A3 subregion.

\section{Six Histone HI Genes Are Present on These YACs}

Probing with a mixture of radiolabeled DNA from two previously identified histone H1-143 (H1c) (Yang et al. 1987), H1-175 (H1e) (Dong et al. 1994), and the H1d gene that we cloned from YAC D6, six potential histone $\mathrm{H} 1$ genes were identified by Southern blotting. All of these $\mathrm{H} 1$ genes have been cloned and sequenced allowing us to identify them as H1a-e (labeled A-E in Fig. $4 \mathrm{~A}$ ) based on the nomenclature of Lennox and Cohen (1984). In addition the testis-specific H1t gene is present in this contig and hybridized weakly with this mixed probe (Fig. 4A, band T). Five of these genes, H1a, H1c, H1d, H1e, and H1t, are located in the first group of YACs, and one, $\mathrm{H} 1 \mathrm{~b}$, is located in the second group (Fig. 4A). The ED11 clone ended in the HindIII fragment containing the H1e gene, resulting in a smaller fragment containing this gene on this YAC (Fig. 4A). 
A

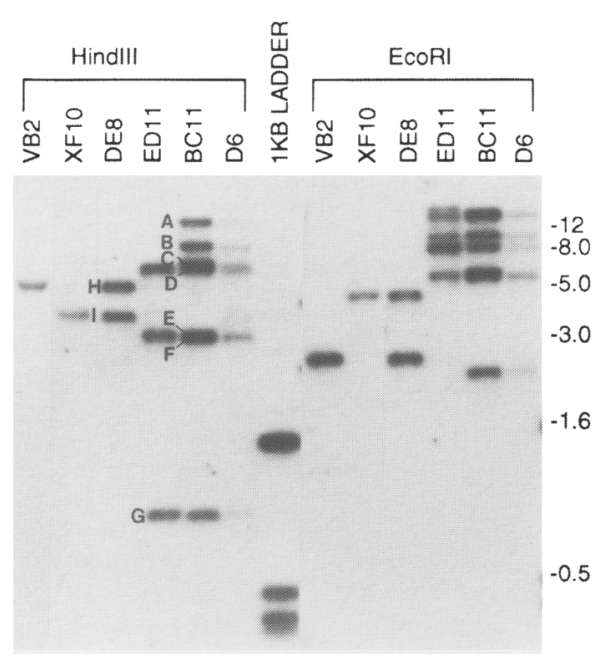

B

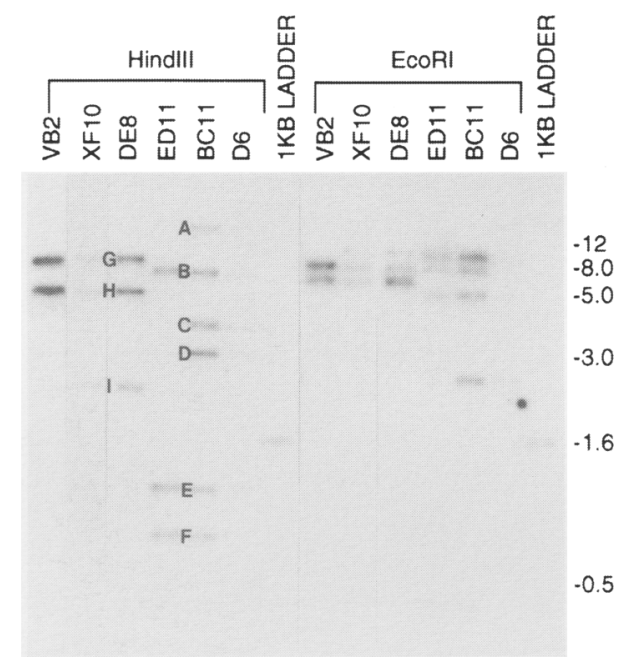

Figure 2 The histone $\mathrm{H} 3$ and histone $\mathrm{H} 4$ genes present on the YACs. Total DNA from yeast strains containing the various YACs was digested with EcoRI or HindIII, and the fragments were resolved by agarose gel electrophoresis and transferred to Nytran. The filters were hybridized with the $\mathrm{H} 3-614$ gene $(A)$ or the $\mathrm{H} 4-12$ gene $(B)$. The $\mathrm{H} 3$ and $\mathrm{H} 4$ genes are lettered $\mathrm{A}-\mathrm{I}$, and this nomenclature is used in the text and in Table 1.

Details of the sequence and expression of the histone $\mathrm{H} 1$ genes will be reported elsewhere (Z.-F. Wang, W.F. Marzluff, A. Sorotkin, and A. Skoultchi, unpubl.).

To confirm the localization of the different $\mathrm{H} 1$ genes, we synthesized primers specific for the H1 genes, H1e (Dong et al. 1994), H1a (Dong et al. 1994), and H1t (Drabent et al. 1993), and used these primers to amplify their respective genes to test for the presence of the different $\mathrm{H} 1$ genes by PCR. Each of these genes was also present on
MOUSE HISIONE GENE CLUSTER ON CHROMOSOME 13

multiple YACs (Fig. 4B), and their approximate location is indicated on the map in Figure 1.

Using the primers specific for the histone H1a gene, we isolated a P1 clone, P318, from a mouse genomic library. In addition to the $\mathrm{H} 1 \mathrm{a}$ gene, this $80-\mathrm{kb}$ P1 clone contains all of the genes from phage MH53 and MM143 (two H3, one H4, two $\mathrm{H} 2 \mathrm{a}$, one $\mathrm{H} 2 \mathrm{~b}$ gene, and the histone $\mathrm{H} 1 \mathrm{c}$ gene), as well as the histone H1t gene and its associated histone $\mathrm{H} 4$ gene (Grimes et al. 1987; Drabent et al. 1995). There is also an additional histone H3 (H3-I), and a histone $\mathrm{H} 4$ gene (H4-B). Thus, within one $80-\mathrm{kb}$ region there are 12 histone genes, with an average spacing of no more than $6 \mathrm{~kb}$.

We have also obtained P1 clones containing most of the histone genes in the second group of YACs (VB2, XF10, and DE8; histone patch I) as well as P1 clones containing multiple histone genes surrounding the H1d gene, which is in patch II. One of these P1 clones, P391, contains both the H1d and H1e genes, and these four P1 clones contain all the $\mathrm{H} 3$ and $\mathrm{H} 4$ genes that are present in patch II. We estimate that the 18 histone genes in patch II are spread over no more than $120 \mathrm{~kb}$.

These P1 clones are consistent with the proposed organization shown in Figure 1, although not all of the histone genes are represented on this set of P1 clones and the precise organization of all the histone genes has not been determined. The positions of the histone $\mathrm{H} 1$ genes and the previously characterized histone gene clusters are indicated on the map in Figure 1.

\section{The Two Groups of YACs Are Overlapping}

Although the two groups of YACs did not contain any histone genes in common, they both mapped to the same region of mouse chromosome 13 (Fig. 3), suggesting that they were tightly linked. To test whether any of the YACs overlapped, we cloned the ends of YACs D6 and XF10 using the "bubble PCR" technique (Riley et al. 1990), and the cloned end fragments were used to probe the DNAs from several YACs to see if they shared common fragments. Because the YACs were constructed by partial digestion with EcoRI, even the terminal EcoRI fragments from overlapping YACs should be identical. One end of the YAC D6 hybridized with both YAC XF10 and YAC D6 (Fig. 5A), whereas the end of YAC XF10 hybridized with YAC D6 and XF10 (data not shown). To confirm this potential overlap, 


\begin{tabular}{|c|c|c|c|c|c|c|c|}
\hline \multirow[b]{2}{*}{ Gene } & \multicolumn{7}{|c|}{ YAC } \\
\hline & D6 & CB11 & CTC4 & ED11 & DE8 & XF10 & VB2 \\
\hline $\begin{array}{l}\mathrm{H} 3 \\
\mathrm{H} 4 \\
\mathrm{H} 1\end{array}$ & $\begin{array}{l}A-G \\
A-F \\
A, C-E, T\end{array}$ & $\begin{array}{l}A-G \\
A-F \\
A, C-E, T\end{array}$ & $\begin{array}{l}A-C, F \\
A, C-E \\
D, E, T\end{array}$ & $\begin{array}{l}\mathrm{D}, \mathrm{E}, \mathrm{G} \\
\mathrm{B}, \mathrm{E}, \mathrm{F} \\
\mathrm{A}, \mathrm{C}, \mathrm{E}, \mathrm{T}\end{array}$ & $\begin{array}{l}H, I \\
G-1 \\
B\end{array}$ & $\begin{array}{l}\text { I } \\
\text { G-I } \\
B\end{array}$ & $\begin{array}{l}\mathrm{H} \\
\mathrm{G}, \mathrm{H}\end{array}$ \\
\hline \multicolumn{8}{|c|}{$\begin{array}{l}\text { The histone } \mathrm{H} 3 \text { and } \mathrm{H} 4 \text { genes present on each of the YACs, as detected by Southern blotting, are shown. There } \\
\text { are nine genes for each of these histones (designated A-I, as shown in Fig. 2). Five of the histone H3 genes } \\
\text { have been reported previously: H3-A, H3.1-221 (Sittman et al. 1983b); H3-C, H3.2-221 (Sittman et al. 1983b); } \\
H 3-E, H 3.2-143 \text { (Brown et al. 1996); H3-G, H3.2-53 (Gruber et al. 1990); and H3-H, H3.1-291 (Taylor et al. } \\
\text { 1986). Two of the histone H4 genes have been reported previously; H4-E, H4-12 (Meier et al. 1989); and H4-F, } \\
\mathrm{H} 4-53 \text { (Meier et al. 1989). The previously cloned H3 genes were identified using PCR primers for each of the } \\
\text { previously cloned phage to map each of the phage reported previously on the YACs. The H3 genes were then } \\
\text { identified by the size of the EcoRl fragment or, in some cases, by cloning and sequencing. The H4 genes were } \\
\text { identified from mapping the MH53 phage (H4-F) and from the fact that the H4-12 gene is adjacent to the H1t } \\
\text { gene (Drabent et al. 1995). The H1 genes are labeled A-E corresponding to the five somatic histone H1 genes } \\
\text { and T for the testis-specific histone H1 gene. The H1A (Dong et al. 1994), H1C (Yang et al. 1987), H1E (Dong } \\
\text { et al. 1994), and H1T (Drabent et al. 1993) genes have been characterized previously. }\end{array}$} \\
\hline
\end{tabular}

primers specific for each of the end fragments were synthesized and the presence of overlapping sequences was determined using PCR. This confirmed that one end of YAC XF10 overlapped with YACs D6, BC11, and CTC4. The end of YAC D6 only overlapped with YAC XF10 and CTC4 (Fig. 5B). Thus, the nine YACs form one large contig. Based on the small size of DE8, which contains all of the genes present on XF10 and VB2 and does not overlap with YAC D6, as well as the $\mathrm{P} 1$ clone P894, which contains all of the histone genes on YAC XF10, as well as some on YAC $\mathrm{VB} 2$, we estimate that there is at least $500 \mathrm{~kb}$ between histone gene patch I on the YAC DE8 and the closest patch of histone genes (patch II) on YAC D6.

\section{The Histone H3 Genes on Mouse Chromosome 13}

The complete histone $\mathrm{H} 3$ gene complement present on mouse chromosome 13 was characterized. There are two replication-dependent histone H3 proteins (Marzluff et al. 1972) that differ from each other in a single amino acid, amino acid 96, which is a serine in H3.2 and a cysteine in H3.1 (Patthy and Smith 1975; Zweidler 1984). Of the five previously characterized histone $\mathrm{H} 3$ genes from mouse chromosome 13, two encode the histone $\mathrm{H} 3.1$ protein and three encode the histone H3.2 protein (Taylor et al. 1986; Gruber et al. 1990; Brown et al. 1996). The remaining four histone $\mathrm{H} 3$ genes from these YACs were iso- lated and sequenced. Two of these genes encoded the H3.1 protein (H3-D and H3-I), and two encoded the $\mathrm{H} 3.2$ protein ( $H 3-B$ and $H 3-F$ ), bringing the complement of mouse histone $\mathrm{H} 3$ genes on chromosome 13 to five histone H3.2 genes and four histone H3.1 genes. The sequences of the coding regions of these nine histone $\mathrm{H} 3$ genes are compared in Figure 6A. There is a clear consensus 411-nucleotide sequence for the coding region, with each gene differing from the consensus in from $0(H 3-H)$ to 7 ( $H 3-C$ and $H 3-G)$ nucleotides, excluding the nucleotide changes associated with the single amino acid change. The amino acid change (Ser $\rightarrow$ Cys) is in a region with 3 nucleotide changes out of four between the $\mathrm{H} 3.2$ and $\mathrm{H} 3.1$ genes, whereas only one of which $(\mathrm{A} \rightarrow \mathrm{T}$ in the first position of codon 96) is necessary for the amino acid change. All of the H3.1 genes are identical in this region differing from all of the H3.2 genes in the same three nucleotides. A 111nucleotide sequence in the center of the gene (amino acids 51-87) is identical in all nine histone $\mathrm{H} 3$ genes. This region contains specific sequences that are necessary for a high level of expression of the histone $\mathrm{H} 3$ genes (Hurt et al. 1989, 1991). The changes are clustered at both the beginning and end of the coding region, consistent with previous studies suggesting repeated gene conversion events targeted at the coding region of the histone genes (Sittman et al. 1983b; Taylor et al. 1986; Liu et al. 1987; Debry and Marzluff 1994). 


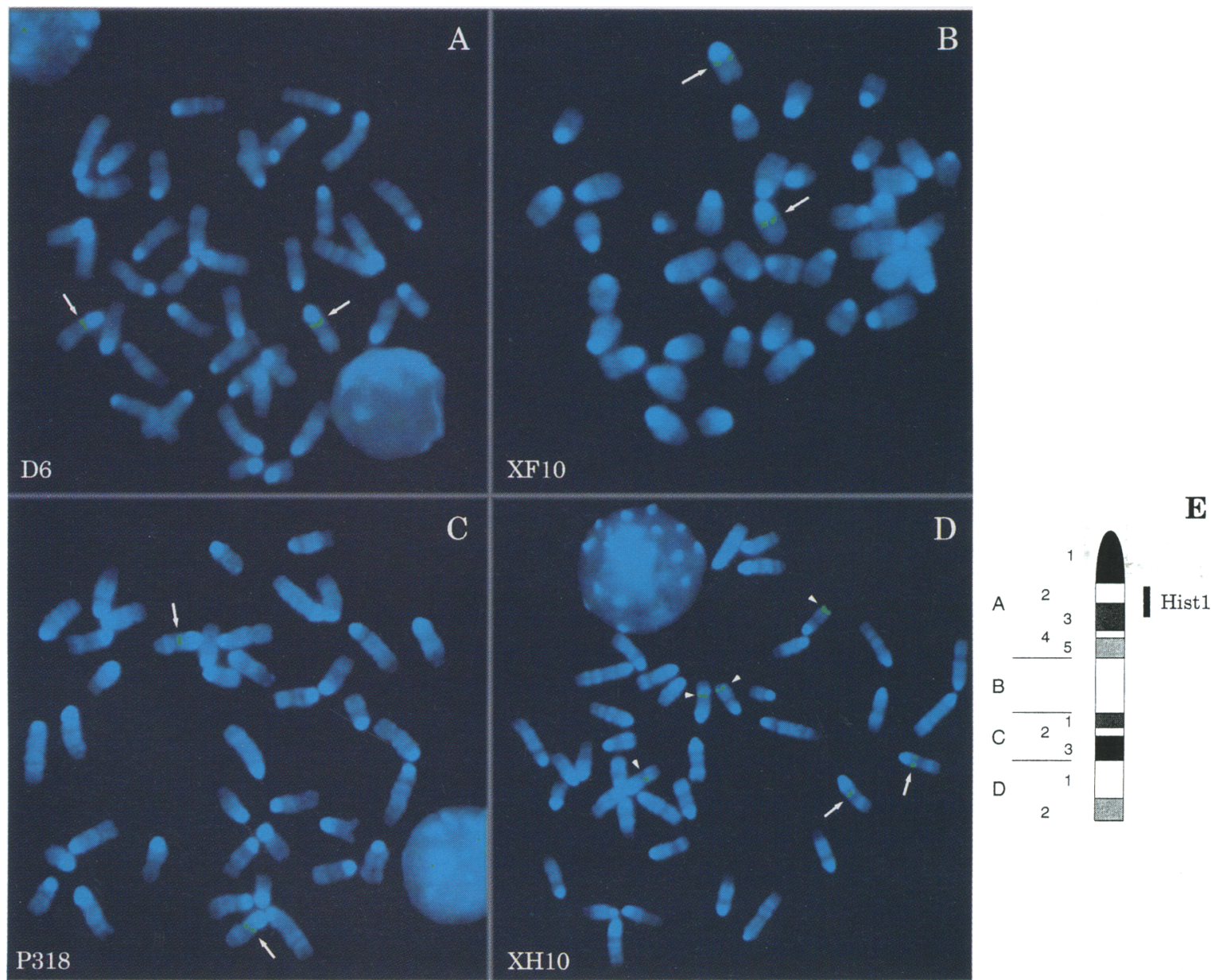

Figure 3 Chromosomal mapping of the mouse Hist1 gene cluster. Clones D6 $(A), X F 10(B)$, and P318 (C) were labeled with biotin and hybridized to the same region of chromosome 13 (green areas, indicated by arrows). The chimeric YAC XH10 clone (D) mapped not only to chromosome 13 but to chromosomes 9 and 17 as well (arrowheads). The G/Q banding pattern was produced by a DAPI counterstain (blue). ( $E$ ) An ideogram of mouse chromosome 13 showing the range of signals (bar at right) on 13A2-3.

The $5^{\prime}$ - and 3 '-flanking sequences of the nine genes are compared in Figure 6, B and C. Of these 18 sequences, 17 are unique, with the sole exception being the 3 '-flanking sequence of $H 3-B$ and $H 3-C$, which are clearly closely related to each other. The 5'-flanking sequences of the $H 3-B$ and $H 3-C$ genes are quite different, as different as any of the other 5'-flanking sequences, and the coding sequences of these two genes differ in 5 nucleotides, most of which are in the $5^{\prime}$ end of the coding region (Fig. 6A).

There are no common sequences present in the 5 '-flanking regions, except for the previously noted TATAA and CCAAT sequences (Taylor et al. 1986). Most of the genes contain at least two CCAAT sequences located within 140 nucleotides of the TATAA box (Fig. 6B), although in two genes (H3.1A and H3.2-B) the CCAAT boxes are much further away. There are no other common elements in the promoter regions of any of the nine histone $\mathrm{H} 3$ genes.

In the 3 '-flanking region the only common sequence among the nine genes is the 26 nucleotides at the $3^{\prime}$ end of the mRNA, which is nearly identical in all nine histone $\mathrm{H} 3$ genes (Fig. 6C). This sequence is located 19-32 nucleotides from the stop codon, and the nucleotides between the stem-loop and the stop codon are not conserved (Fig. 6C). In contrast, the U7 snRNA binding site located 3' of the stem-loop is quite variable among the different histone $\mathrm{H} 3$ genes, both in sequence and in distance from the $3^{\prime}$ end of the histone mRNA (Fig. 6C).

\section{Expression of the Histone H3 Genes}

We used S1 nuclease mapping to determine whether all of the histone $\mathrm{H} 3$ genes are expressed 
WANG ET AL.

A

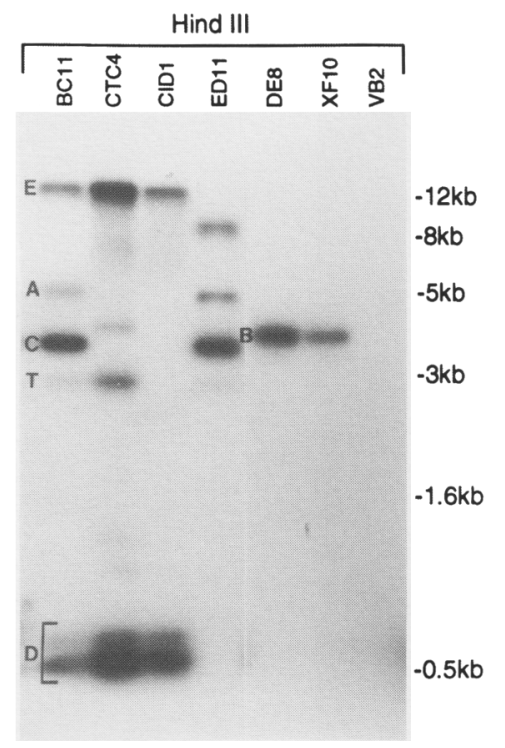

B
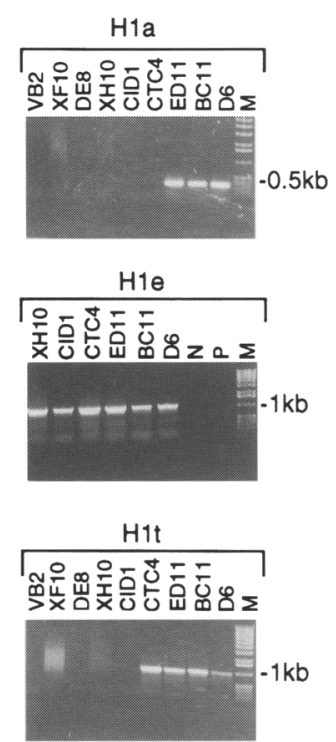

Figure 4 Detection of histone $\mathrm{H} 1$ genes on the YACs. $(A)$ DNA from yeast strains containing the indicated YACS was digested with HindllI, the fragments were resolved by agarose gel electrophoresis, and transferred to Nytran. The filter was hybridized with a mixture of probes of $\mathrm{H} 1 \mathrm{c}, \mathrm{H} 1 \mathrm{~d}$, and $\mathrm{H} 1 \mathrm{e}$. The bands are labeled $\mathrm{A}-\mathrm{E}, \mathrm{T}$, corresponding to the $\mathrm{H} 1 \mathrm{a}-\mathrm{e}$ genes and the $\mathrm{H} 1 \mathrm{t}$ gene. The $\mathrm{H} 1 \mathrm{t}$ gene (band $\mathrm{T}$ ) hybridized more weakly than the other $\mathrm{H} 1$ genes. The YAC ED11 ended near the $\mathrm{H} 1 \mathrm{e}$ gene, resulting in a 9-kb fragment rather than the 15-kb fragment detected in the other YACs. (B) To confirm the presence of the previously cloned histone $\mathrm{H} 1$ genes on the YACs, primers specific for the $\mathrm{H} 1 \mathrm{a}$ (top), $\mathrm{H} 1 \mathrm{e}$ (middle), and $\mathrm{H} 1 \mathrm{t}$ (bottom) genes were used to amplify the various yeast DNAs. The PCR products were resolved by agarose gel electrophoresis and detected by ethidium bromide staining. The YAC DNAs used are indicated above each lane.

and to determine the relative level of expression of each of the genes. All of the histone $\mathrm{H} 3$ genes have a Sall site spanning codon 58. Each gene was digested with Sall and either the $3^{\prime}$ end was labeled with Klenow fragment of DNA Pol I or the $5^{\prime}$ end was labeled with T4 polynucleotide kinase. Because the coding regions are conserved, each of these probes will hybridize to all the histone $\mathrm{H} 3$ mRNAs derived from chromosome 13, with the hybrids extending to the end of the coding region, either to the initiation codon or the translation stop codon (Sittman et al. 1983a; Graves et al. 1985) depending on whether the probe was $5^{\prime}$ or $3^{\prime}$ end-labeled. Each probe will also hybridize with the mRNA derived from that particular gene, with the hybrid extending to the end of the mRNA. Two fragments are protected from digestion with $\mathrm{S} 1$ nuclease, one $\left(\mathrm{H} 3_{\mathrm{M}}\right)$ extending to the end of the coding region, and the other (H3) to the end of the mRNA expressed from the gene used as a probe. The intensity of the $\mathrm{H} 3_{\mathrm{M}}$ fragment is a measure of the amount of the total cellular $\mathrm{H} 3$ replication-dependent histone mRNA, whereas the intensity of the specific $\mathrm{H} 3$ band is a measure of the amount of a specific $\mathrm{H} 3$ mRNA. The relative intensity of these two fragments reflects the percentage of the histone $\mathrm{H} 3 \mathrm{mRNA}$ derived from the gene used as a probe.

The expression of each of these genes was analyzed in cultured mouse myeloma cells and in newborn mice, and similar results were found with both samples. We have shown previously that the H3-A, H3-C, H3-E, and $H 3-H$ genes are expressed at low levels, accounting for $<10 \%$ of the total histone $\mathrm{H} 3 \mathrm{mRNA}$ (Graves et al. 1985; Brown et al. 1996). Each of the other five genes was expressed in both RNA samples (Fig. 7; data not shown). Each of these genes also produces a small fraction of the total histone $\mathrm{H} 3 \mathrm{mRNA}, 3 \%-10 \%$ of the total, based on the ratio of intensities of the protected band extending to the start of the mRNA to the band extending to the end of the coding region. It is likely that the same situation holds for the genes for the other core histones on chromosome 13. Thus, there are nine distinct nonallelic histone $\mathrm{H} 3$ genes located on mouse chromosome 13 , each of which contributes only a small fraction of the total histone $\mathrm{H} 3$ mRNA.

\section{DISCUSSION}

Histone proteins must be synthesized at a very high rate during $S$ phase to package the newly replicated DNA, and the core histone proteins are produced in equimolar amounts. The high demand for histone mRNA to synthesize the $10^{8}$ histone proteins required in each $S$ phase presumably requires multiple copies of the histone genes. Because histone mRNAs have a relatively short half-life $(\sim 1 \mathrm{hr})$ (Heintz et al. 1983; Stimac et al. 1984; Harris et al. 1991) even during $S$ 


\section{MOUSE HISIONE GENE CLUSTER ON CHROMOSOME 13}

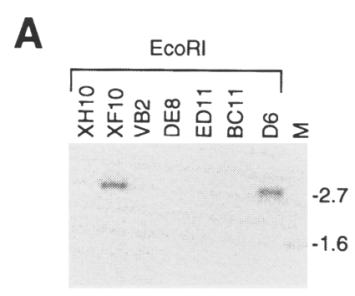

B

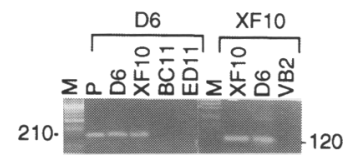

Figure 5 The two YAC contigs are overlapping. (A) The end fragment of the YAC D6 clone was isolated and used as a probe against various YAC DNAs in a Southern blot digested with EcoRl. The size of the markers (in $\mathrm{kb}$ ) is indicated. (B) Primers were synthesized that specifically amplify the end fragments of YAC D6 as a 210-nucleotide fragment and YAC XF10 as a 120-nucleotide fragment. PCR was performed using these primers against several YAC DNAs. The PCR products were resolved by agarose gel electrophoresis and detected using ethidium bromide staining.

phase, there must be a continuing high rate of histone mRNA synthesis during $S$ phase. Therefore, it is likely that histone proteins are encoded by a multigene family to allow the rapid production of large amounts of histone mRNA and proteins. Jacob (1976) estimated that the core histone proteins are encoded by a multigene family containing 10-20 copies of the histone genes. Most of these genes have now been isolated, and we estimate that there are a total of 11-14 genes for each core histone, which is in excellent agreement with the initial estimate of Jacob (1976).

Studies using $\lambda$ phage have shown that there are often multiple histone genes in mammals located on a single $15-\mathrm{kb}$ phage, suggesting that many histone genes are very tightly linked (Heintz et al. 1981; Sierra et al. 1982). However, definitive information on the overall organization is not known. We have shown here that the histone genes on mouse chromosome 13 are not uniformly spaced but, rather, there are three patches of histone genes spread out over at least $1 \mathrm{Mb}$ of DNA. The histone genes are $0.5-5 \mathrm{~kb}$ apart within the patches, but the distance between patches is at least $500 \mathrm{~kb}$ in one case, i.e., between patches I and II. It is not known whether there are any other genes located in the regions between the histone patches. Given the large size of these regions, it seems very likely that other genes are present here. Whether any genes present in these regions are also cell cycle-regulated will be of particular interest.

Each of the three patches contains multiple histone genes and at least one histone $\mathrm{H} 1$ gene. Patch I, present on the second group of YACs, VB2, XF10, and DE8, contains one histone H1 gene, H1b, along with 14 genes encoding the four core histones. Patch II contains the H1e and H1d genes, in addition to 16 core histone genes. Patch III, defined by the P1 clone P318, contains three histone $\mathrm{H} 1$ genes, $\mathrm{H} 1 \mathrm{c}, \mathrm{H} 1 \mathrm{a}$, and $\mathrm{H} 1 \mathrm{t}$, as well as nine core histone genes, including the previously characterized phage MM143 (Yang et al. 1987) and clone 53 (Gruber et al. 1990). Note that the testis-specific H1t is located near the center of the entire cluster, at one end of patch III.

The histone gene cluster on mouse chromosome 13 is likely orthologous with the histone gene cluster on human chromosome 6 . All of the histone $\mathrm{H} 1$ genes, except the gene for histone $\mathrm{H} 1^{0}$, which is encoded by a polyadenylated mRNA, are present on human chromosome 6 (Doenecke et al. 1994). Likewise, all of the mouse histone $\mathrm{H} 1$ genes, except for $\mathrm{H} 1^{\circ}$, are in the cluster from chromosome 13. The detailed organization of the histone gene cluster on human chromosome 6 is not known, and it will be of interest to see whether the patch organization has been maintained during mammalian evolution. There has clearly been conservation of the gene organization within mammals at some level, as there is a histone $\mathrm{H} 4$ gene closely linked with the histone H1t gene in both rodents and humans (Drabent et al. 1995). The extent of conservation of organization throughout the entire cluster awaits characterization of the human gene cluster.

It is likely that a similar organization of histone genes is present in most vertebrates, with the exception of amphibians (Turner and Woodland 1983; Destree et al. 1984) where many, if not all, of the histone genes are tandemly repeated. All of the replication-dependent chicken histone genes have been cloned and mapped using overlapping $\lambda$ phage, and they fall into two clusters (Grandy and Dodgson 1987; Nakayama et al. 1993). It is not known whether these two clusters are present on different chromosomes, or whether they are two clusters on the same chromosome, analogous to the genes located on mouse chromosome 13 . The genes in each cluster are relatively close together, as the entire cluster was defined by overlapping $\lambda$ phage (Grandy and 


\section{WANG ET AL.}

A

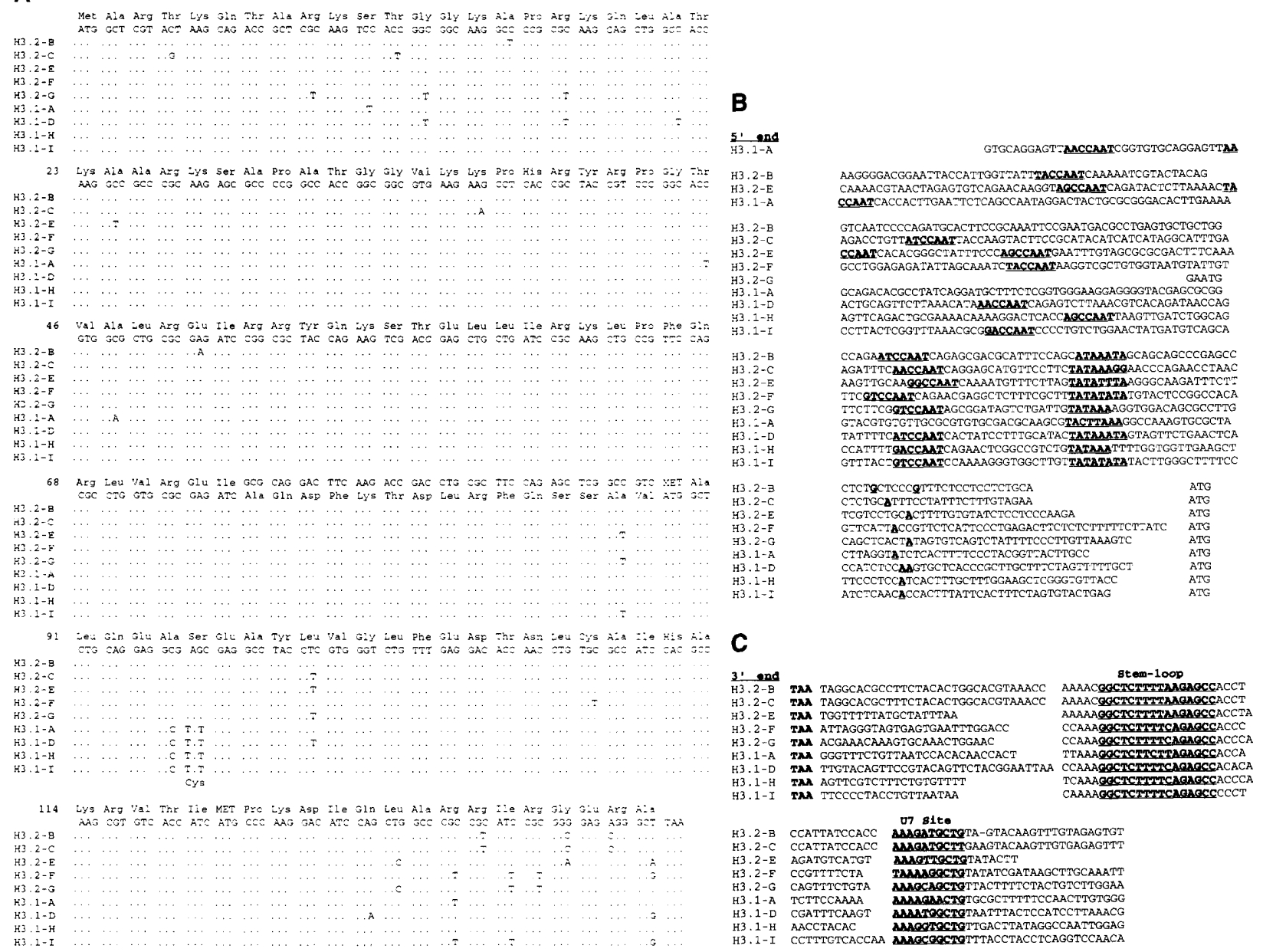

Figure 6 Comparison of histone $\mathrm{H} 3$ gene sequences. $(A)$ Coding region of all nine histone $\mathrm{H} 3 \mathrm{genes}$. The five histone $\mathrm{H} 3.2$ genes and the four histone $\mathrm{H} 3.1$ genes are compared in the coding region. A consensus nucleotide sequence for these nine genes is shown at the top. The histone $H 3$ genes sequenced previously $(A, C, E, G$, and $\mathrm{H})$ are identified in Table 1. (B) The $5^{\prime}$-flanking regions of the nine histone $\mathrm{H} 3$ genes. The transcription start site, the TATAA box, and the CCAAT boxes are underlined. The sequence of only 80 nucleotides $5^{\prime}$ of the $\mathrm{H3.2-G}$ gene was determined previously (Meier et al. 1989). The sequences shown extend to include at least two of the CCAAT boxes found in the promoter of each gene. $(C)$ The 3 '-flanking region of all nine histone $\mathrm{H} 3 \mathrm{genes}$. The stem-loop at the $3^{\prime}$ end of the mRNA and the U7 snRNP binding site are underlined. The end of the histone mRNA is the last nucleotide in the first line.

Dodgson 1987). Because there are histone $\mathrm{H} 1$ genes present on both of the chicken histone gene clusters (Nakayama et al. 1993), it is likely that these clusters are present on the same chromosome and are closely linked. All of the chicken $\mathrm{H} 2 \mathrm{~b}$ genes have been cloned and sequenced (Grandy and Dodgson 1987). The sequences of the different chicken histone $\mathrm{H} 2 \mathrm{~b}$ genes also have strikingly conserved coding regions, with each gene having distinct flanking regions (Grandy and Dodgson 1987). The expression level of the individual chicken histone $\mathrm{H} 2 \mathrm{~b}$ genes was not determined.

\section{Gene Conversion Among the Core Histone Genes}

We have proposed previously that the mouse histone genes have undergone gene conversion targeted at the coding region, based on the presence of H2a pseudogenes (located on chromosome 13), which are nearly identical in nucleotide sequence with the authentic $\mathrm{H} 2 \mathrm{a}$ genes on chromosome 13 (Liu et al. 1987; Brown et al. 1996). The coding regions of the other core histone genes are also remarkably similar at the nucleotide level (Taylor et al. 1986; Liu et al. 1989). It is possible that there has been selection on the 

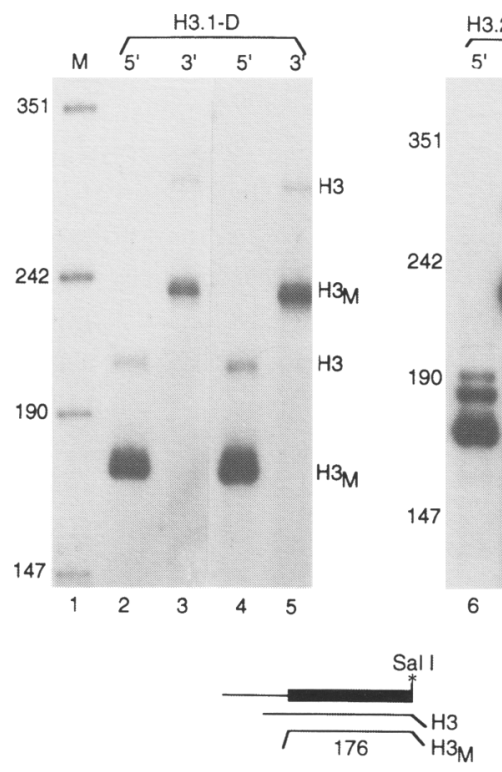
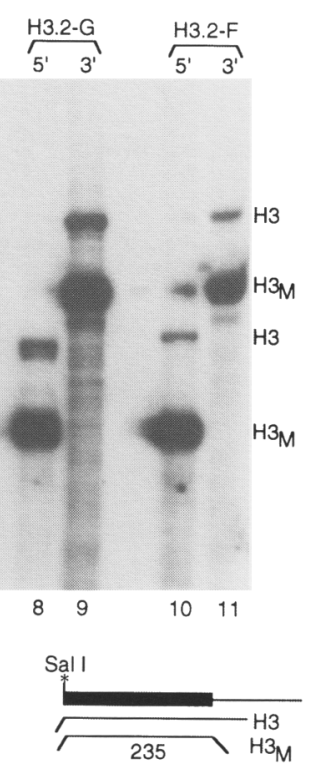

Figure 7 Expression of the histone $\mathrm{H} 3$ genes. The histone $H 3-B, H 3-D, H 3-F$, $H 3-G$, and $H 3-1$ genes were labeled at either the $3^{\prime}$ or the $5^{\prime}$ end of the Sall site at codon 58. These probes were hybridized to $5 \mu \mathrm{g}$ of total cell RNA from newborn mice (lanes 2,3) or mouse myeloma cells (lanes 4-13), and the S1-resistant fragments were resolved by polyacrylamide gel electrophoresis and detected by autoradiography. The probes used are indicated above each panel. The $5^{\prime}$ probes protected a fragment of 176 nucleotides $\left(\mathrm{H} 3_{M}\right)$ extending to the start codon as a result of protection by the other histone mRNAs, and a longer fragment $(\mathrm{H} 3)$ extending to the end of the mRNA derived from the gene used as a probe. Similarly the $3^{\prime}$ probe protected a fragment of 235 nucleotides $\left(\mathrm{H}_{3} \mathrm{M}\right)$ extending to the stop codon as a result of protection by all the other histone mRNAs, and a longer fragment $(\mathrm{H} 3)$ extending to the end of the mRNA derived from the gene used as a probe. A diagram of the nuclease protection assay is shown at the bottom.

nucleotide sequence of the coding region (Debry and Marzluff 1994), together with frequent gene conversion among the coding regions of individual genes to maintain the nearly identical coding region sequences in the replicationdependent histone gene family (Debry and Marzluff 1994).

Here we have reported the complete sequence of all nine of the histone $\mathrm{H} 3$ genes on mouse chromosome 13. Each of these nine genes is expressed, contributing a small fraction of the total histone H3 mRNA. Five of these genes encode histone $\mathrm{H} 3.2$ proteins and four encode histone H3.1 proteins. The histone H3.2 protein is the predominant histone $\mathrm{H} 3$ protein present in rodents, making up $-80 \%$ of the total histone $\mathrm{H} 3$ protein (Zweidler 1984). The high level of the H3.2 protein is a result of the presence of highly active histone $\mathrm{H} 3$ genes on mouse chromosome 3 , which also encode the histone $\mathrm{H} 3.2$ protein
(Graves et al. 1985; Wang et al., this issue). In cattle (Marzluff et al. 1972; Patthy and Smith 1975) and in humans (Wu and Bonner 1981) the major histone $\mathrm{H} 3$ is the histone $\mathrm{H} 3.1$ protein. Assuming a similar gene organization in humans and mice, we predict that the histone $\mathrm{H} 3$ genes present on human chromosome 1 will encode histone H3.1 proteins.

The coding regions of the histone $\mathrm{H} 3$ genes on mouse chromosome 13 have been remarkably conserved at the nucleotide level. There is a clear consensus at every nucleotide, with the exception of the single amino acid difference between histone H3.1 and H3.2. At this site, there is a characteristic 3-nucleotide difference between the H3.1 and H3.2 genes, in the third nucleotide of codon 95 and the first and third nucleotide of codon 96 (although the amino acid change could be accomplished by simply changing the first nucleotide of codon 96). There are very few changes among all of the histone $\mathrm{H} 3$ genes (seven variant positions) between codons 30 and 124, but there are nine changes in the last 10 codons and seven changes in the first 30 codons. It is difficult to reconcile the near identity in the coding region with the 3-nucleotide changes present between the H3.1 and H3.2 genes, which are in a region where all the genes are otherwise nearly identical. If these three changes are not included, then the H3.1 and H3.2 genes are equally similar to each other.

In one case there has been a recent gene conversion event that extended past the coding region. The 3'-flanking regions of the $\mathrm{H3}-\mathrm{C}$ and $H 3-B$ genes are nearly identical for $>150$ nucleotides past the stop codon. The 5 '-flanking regions of these same genes are completely distinct (Fig. $6 \mathrm{~B})$, suggesting that the conversion event extended from the coding region to the 3 '-flanking region of the gene. These two genes are located in 


\section{WANG ET AL.}

the same patch (patch II) suggesting that these tightly linked genes were involved in a recent gene conversion event. Note that these genes have 5-nucleotide changes in the $5^{\prime}$ end of the coding region, a number similar to that found between any two histone $\mathrm{H} 3$ genes.

\section{Why Are the Histone Genes Clustered?}

The histone genes encode five distinct families of proteins, and the four core histone proteins have been highly conserved at the amino acid levels in all metazoans and plants. Unlike the genes for many coordinately expressed proteins (e.g. $\alpha$ and $\beta$-globin), the genes for the different histone proteins have remained tightly linked during evolution. This is a unique organization for a coordinately regulated gene family in metazoans, particularly one in which the five proteins are so different from one another. The mRNAs encoding the replication-dependent histone proteins are unique, in that they are the only nonpolyadenylated mRNAs (Marzluff 1992). They end instead in a highly conserved stem-loop structure that is present on all replication-dependent histone mRNAs. Despite the fact that the genes for the different histones are linked, there are two clusters of histone genes in mammals.

There must be selective pressure maintaining the different histone genes in a tightly linked cluster. The selective pressure that has kept the histone genes relatively closely linked may be the unique mechanism of histone mRNA synthesis in metazoans. The replication-dependent histone pre-mRNAs must take a different pathway through the nucleus than the other pre-mRNAs. The histone genes lack introns and the 3 ' ends are formed by a cleavage reaction requiring U7 small nuclear ribonucleoprotein (snRNP) (Gick et al. 1986; Mowry and Steitz 1987; Soldati and Schümperli 1988). It is possible that the clustering of the histone genes is attributable to the need to efficiently process the histone mRNA, which may take place at defined subnuclear sites that are close to the histone genes. There is evidence for discrete subnuclear structures located near the histone genes (Frey and Matera 1995) that contain U7 snRNA. The one exception to this clustering is the H2a.X gene, which ends in the same stem-loop (Mannironi et al. 1989; Nagata et al. 1991) and is located on human chromosome 11 (Ivanova et al. 1994), in a different location from the other histone genes. The H2a.X gene encodes both a replication-dependent mRNA and a polyadenylated mRNA (Mannironi et al. 1989; Nagata et al. 1991). We have noted that there are cases where a transfected replication-dependent histone gene produces some polyadenylated mRNA, whereas the endogenous gene does not, suggesting that the chromosomal localization may influence the efficiency of histone 3'-end formation (Chodchoy et al. 1987). If histone processing is tightly coupled with transcription in vivo, a prediction is that there are at least two centers of histone pre-mRNA processing, one for chromosome 3 and the other for chromosome 13 . The two histone gene clusters could be in close proximity in the nucleus. These possibilities are currently under investigation.

\section{METHODS}

\section{Isolation of YAC and PI Clones}

Pooled DNA from the mouse YAC library (Princeton University, $\mathrm{NJ}$ ) was screened by PCR using primers from the coding region of mouse histone H3. Primer 1 extended from codon 12 to 18 (GGCGGCAAGGCCCCGCGCAA) and primer 2 from codon 126 to 119 (CTGGATGTCCTTGGGCATGATGGT). Nine YACs containing the histone genes were identified using PCR. The YAC sizes were determined by pulsed-field gel electrophoresis (Schwartz and Cantor 1984), followed by Southern blotting using a probe from the coding region of histone H3. DNA was prepared from each of the yeast strains by the method of Olsen et al. (1979). The DNA was digested with restriction enzymes, separated by agarose gel electrophoresis and transferred to Nytran. Probes specific for each of the four core histone genes were used to estimate the number of each type of histone gene on each YAC.

The P1 clone P318 was isolated by Genome Systems (St. Louis, MO) using primers specific for the histone $\mathrm{H} 1 \mathrm{a}$ gene (Dong et al. 1994). Additional P1 clones were isolated using primers specific for the histone H1b (P894), H1d (P271, P895, P896), and H1e (P391) genes.

\section{Identification of the Ends of the YAC Clones}

The ends of the YAC inserts were identified by bubble PCR (Riley et al. 1990). The yeast DNA was digested with several restriction enzymes that result in blunt-end DNA fragments, a bubble primer was ligated onto the end of the fragments, and the fragments where linearly amplified for 10 cycles using a single primer complementary to one end of the YAC vector. The end fragments were then amplified for 30 cycles using a primer complementary to the bubble and a nested primer specific for one side of the insertion site in the YAC. The amplified fragments were then cloned into pUC18. The fragments were sequenced to verify that they contained the insertion sites of the YACs. The end fragments were labeled using random primer labeling and hybridized to a Southern blot containing DNA from all of the YACs. Specific primers for the insert were synthesized 
based on the sequence, and all of the YACs were tested by PCR for the presence of these end fragments.

\section{In Situ Hybridization}

Mouse metaphase spreads were prepared from cultured spleenocytes using a standard methanol/acetic acid fixation protocol. The following YAC clones were used for fluorescence in situ hybridization (FISH): BC11, CTC4, D6, DE8, ED11, VB2, XF10, XH10, CID1, and P318 (a P1 clone). The probes were nick-translated, incorporating biotin-16-dUTP (Boehringer Mannheim, Indianapolis, IN). Approximately $500 \mathrm{ng}$ of total yeast DNA (or 70-80 ng of P1 DNA) was precipitated along with $2 \mu \mathrm{g}$ of mouse Cot- 1 DNA (GIBCO/BRL, Gaithersburg, MD) and $9 \mu \mathrm{g}$ of salmon sperm DNA for use on each metaphase slide. The probe solution consisted of $50 \%$ formamide $/ 2 \times \mathrm{SSC} / 10 \% \mathrm{dex}$ tran sulfate at $37^{\circ} \mathrm{C}$; subsequent washings $3 \times 5 \mathrm{~min}$ each) were performed in $50 \%$ formamide $2 \times$ SSC at $42^{\circ} \mathrm{C}$ and then in $1 \times \mathrm{SSC}$ at $60^{\circ} \mathrm{C}$. The hybridization signals were detected with FITC-cojugated avidin (Vector Laboratories, Burlingame, CA). The G/Q banding pattern on the chromosomes was generated by a DAPI counterstain.

The metaphase chromosomes were imaged using a cooled charge-coupled device (CCD) camera (Photometrics, Tucson, AZ). The 16-bit source images were stored as normalized 8-bit gray scale data files by use of the software program CCD Image Capture (Yale University, New Haven, $C T$ ). Proper image registration was maintained by the use of highly plane parallel bandpass filters (Ballard and Ward 1993). Image merging and pseudocoloring were done with the use of Gene Join (Yale University) on an Apple Macintosh computer. Finished color prints were produced using Adobe Photoshop 2.5.1 (Adobe Systems) and a dye sublimation printer (Kodak).

\section{Identification of the Histone $\mathrm{H} 3$ Genes}

To identify the previously isolated histone gene clusters, primers from the $5^{\prime}$ - and 3 '-flanking region were utilized in PCR reactions with total DNA from yeast strains containing the YACs. This strategy allowed us to identify all of the previously reported mouse histone genes on chromosome 13. To isolate the additional histone $\mathrm{H} 3$ genes, the yeast DNA was digested with the appropriate restriction enzyme and then resolved by electrophoresis on a $1 \%$ agarose gel. The region containing the histone $\mathrm{H} 3$ genes identified by Southern blotting was eluted and the DNA cloned into pGEM3zf, pUC18, or pBluescript. The positive clones were identified by colony hybridization (Buluwela et al. 1989) using the H3-614 gene as a probe.

\section{Analysis of Histone H3 Gene Expression}

All of the histone $\mathrm{H} 3$ genes contain a Sall site in the coding region at codon 58 . The cloned gene was digested with Sall, and the $3^{\prime}$ end was labeled with $\left[\alpha^{-32} \mathrm{P}\right] \mathrm{dC} T \mathrm{P}$ using the Klenow fragment of DNA Poll. To label the 5' end, the digested DNA was treated with calf intestinal phosphatase followed by labeling with $\left[\gamma_{-}{ }^{32} \mathrm{P}\right] \mathrm{ATP}$ using T4 polynucleotide kinase. The labeled DNA was hybridized with $5 \mu \mathrm{g}$ of RNA from either mouse myeloma cells or newborn mice.
S1 nuclease protection assays were performed as described previously (Graves et al. 1985). The protected fragments were analyzed by electrophoresis on $6 \%$ polyacrylamide $/ 7$ $\mathrm{M}$ urea gels and detected by autoradiography.

\section{Identification of Individual Histone $\mathrm{HI}$ Genes by PCR}

Primers specific for the histone H1a (Dong et al. 1994), H1e (Dong et al. 1994), and H1t (Drabent et al. 1993) genes were synthesized and used in a PCR reaction to amplify the individual $\mathrm{H} 1$ genes. The H1a primers were from the 5' untranslated region (UTR) (TGCAGGCAGACAGGCGCACG) and from the center of the coding region (TGCACGATGAGCTCCGACAC), and the PCR-amplified product was 310 nucleotides. The H1e primers were from the 5'(TGCATGAAGCCCGAGACTTC) and $3^{\prime}$-(CTAACCACACCCCCTGTGAATG) flanking regions, and the PCR amplified product was 1042 nucleotides. The $\mathrm{H} 1 \mathrm{t}$ primers were from the 5'-(GTCGCGTGGAATCTAAGTCC) and $3^{\prime}$ (AACTGCCCACCTTAACTTTGG) flanking regions, and the PCR amplified product was 994 nucleotides.

\section{DNA Sequencing}

The DNA was sequenced on an Applied Biosystems Model 373A sequencer in the DNA Sequencing Facility at the University of North Carolina at Chapel Hill. Both strands of all genes were sequenced.

\section{ACKNOWLEDGMENTS}

This work was supported by National Institutes of Health (NIH) grant GM 29832 to W.F.M. and grants JFRA-570 from the American Cancer Society and GM 53034 from NIH to A.G.M. We thank Dr. Laura Livingstone and Jenifer Langdon in the University of North Carolina DNA Sequencing Facility for their help in this work. We thank Dr. Jeff Dangl for advice on the bubble PCR, Anne Whalen for help with the metaphase analysis, and Drs. David Koos and Shirley Tilghman for the YAC library. The sequence data described in this paper have been submitted to the GenBank data library under the following accession numbers: H3-A, X01684; H3-B, U62671; H3-C, X01685; H3-D, U62672; H3-E, X80328; H3-F, U62669; H3-G, M33989; H3-H, M32462; H3-I, U62670.

The publication costs of this article were defrayed in part by payment of page charges. This article must therefore be hereby marked "advertisement" in accordance with 18 USC section 1734 solely to indicate this fact.

\section{REFERENCES}

Allen, B.S., J.L. Stein, G.S. Stein, and H. Ostrer. 1991. Single-copy flanking sequences in human histone gene clusters map to chromosomes 1 and 6 . Genomics 10: $486-488$.

Ballard, S.G. and D.C. Ward. 1993. Fluorescence in situ hybridization using digital imaging microscopy. $J$. Histochem. Cytochem. 41: 1755-1759. 
WANG ET AL.

Birnstiel, M.L., M. Busslinger, and K. Strub. 1985. Transcription termination and 3' processing: The end is in site! Cell 41: 349-359.

Brown, V.D., Z.-F. Wang, A.S. Williams, and W.F. Marzluff. 1996. Structure of a cluster of mouse histone genes. Biochim. Biophys. Acta Gene Struct. Expression 1306: 17-22.

Brush, D., J.B. Dodgson, O.R. Choi, P.W. Stevens, and J.D. Engel. 1985. Replacement variant histone genes contain intervening sequences. Mol. Cell. Biol. 5: $1307-1317$.

Buluwela, L., A. Forster, T. Boehm, and T.H. Rabbits. 1989. A rapid procedure for colony screening using nylon filters. Nucleic Acids Res. 17: 452.

Chodchoy, N., B.J. Levine, C. Sprecher, A.I. Skoultchi, and W.F. Marzluff. 1987. Expression of mouse histone genes: Transcription into 3' intergenic DNA and cryptic processing sites downstream from the $3^{\prime}$ end of the $\mathrm{H} 3$ gene. Mol. Cell. Biol. 7: 1039-1047.

Debry, R.W. and W.F. Marzluff. 1994. Selection on silent sites in the rodent $\mathrm{H} 3$ histone gene family. Genetics 138: 191-202.

Destree, O.H., M.M. Bendig, R.T. De Laaf, and J.G. Koster. 1984. Organization of Xenopus histone gene variants within clusters and their transcriptional expression. Biochim. Biophys. Acta 782: 132-141.

Doenecke, D., W. Albig, H. Bouterfa, and B. Drabent. 1994. Organization and expression of $\mathrm{H} 1$ histone and H1 replacement histone genes. J. Cell. Biochem.

54: $423-431$.

Dong, Y., A.M. Sirotkin, Y.-S. Yang, D.T. Brown, D.B. Sittman, and A.I. Skoultchi. 1994. Isolation and characterization of two replication-dependent mouse H1 histone genes. Nucleic Acids Res. 22: 1421-1428.

Drabent, B., C. Bode, and D. Doenecke. 1993. Structure and expression of the mouse testicular $\mathrm{H} 1$ histone gene (H1t). Biochim. Biophys. Acta Gene Struct. Expression 1216: $311-313$.

Drabent, B., E. Kardalinou, C. Bode, and D. Doenecke. 1995. Association of histone $\mathrm{H} 4$ genes with the mammalian testis-specific H1t histone gene. DNA Cell Biol. 14: 591-597.

Fecker, L., P. Ekblom, M. Kurkinen, and M. Ekblom. 1990. A genomic clone encoding a novel proliferation-dependent histone H2A.1 mRNA enriched in the poly(A) ${ }^{+}$fraction. Mol. Cell. Biol. 10: 2848-2854.

Frey, M.R. and A.G. Matera. 1995. Coiled bodies contain U7 small nuclear RNA and associate with specific DNA sequences in interphase human cells. Proc. Natl. Acad. Sci. 92: 5915-5919.

Gick, O., A. Krämer, W. Keller, and M.L. Birnstiel. 1986. Generation of histone mRNA 3' ends by endonucleolytic cleavage of the pre-mRNA in a snRNP-dependent in vitro reaction. EMBO J. 5: 1319-1326.
Grandy, D.K. and J.B. Dodgson. 1987. Structure and organization of the chicken $\mathrm{H} 2 \mathrm{~B}$ histone gene family. Nucleic Acids Res. 15: 1063-1080.

Graves, R.A., S.E. Wellman, I.-M. Chiu, and W.F. Marzluff. 1985. Differential expression of two clusters of mouse histone genes. J. Mol. Biol. 183: 179-194.

Grimes, S., P. Weisz-Carrington, H. Daum III, J. Smith, L. Green, K. Wright, G. Stein, and J. Stein. 1987. A rat histone $\mathrm{H} 4$ gene closely associated with the testis-specific H1t gene. Exp. Cell. Res. 173: 534-545.

Gruber, A., A. Streit, M. Reist, P. Benninger, R. Böhni, and D. Schümperli. 1990. Structure of a mouse histone-encoding gene cluster. Gene 95: 303-304.

Harris, M.E., R. Böhni, M.H. Schneiderman, L. Ramamurthy, D. Schümperli, and W.F. Marzluff. 1991. Regulation of histone mRNA in the unperturbed cell cycle: Evidence suggesting control at two posttranscriptional steps. Mol. Cell. Biol. 11: 2416-2424.

Heintz, N., M. Zernik, and R.G. Roeder. 1981. The structure of the human histone genes: Clustered but not tandemly repeated. Cell 24: 661-668.

Heintz, N., H.L. Sive, and R.G. Roeder. 1983. Regulation of human histone gene expression: Kinetics of accumulation and changes in the rate of synthesis and in the half-lives of individual histone mRNAs during the HeLa cell cycle. Mol. Cell. Biol. 3: 539-550.

Hurt, M.M., N.B. Pandey, and W.F. Marzluff. 1989. A region in the coding sequence is required for high-level expression of murine histone H3 gene. Proc. Natl. Acad. Sci. 86: 4450-4454.

Hurt, M.M., T.L. Bowman, and W.F. Marzluff. 1991. A common transcriptional activator is located in the coding region of two replication-dependent mouse histone genes. Mol. Cell. Biol. 11: 2929-2936.

Ivanova, V.S., D. Zimonjic, N. Popescu, and W.M. Bonner. 1994. Chromosomal localization of the human histone H2A.X gene to 11q23.2-q23.3 by fluorescence in situ hybridization. Hum. Genet. 94: 303-306.

Jacob, E. 1976. Histone gene reiteration in the mouse. Eur. J. Biochem. 65: 275-284.

Kornberg, R.D. 1977. Structure of chromatin. Annu. Rev. Biochem. 46: 931-954.

Kosciessa, U. and D. Doenecke. 1989. Nucleotide sequences of mouse histone genes $\mathrm{H} 2 \mathrm{~A}$ and H3.1. Nucleic Acids Res. 17: 8861.

Lennox, R.W. and L.H. Cohen. 1984. The H1 subtypes of mammals: Metabolic characteristics and tissue distribution. In Histone genes: Structure, organization and regulation (ed. G.S. Stein, J.L. Stein, and W.F. Marzluff), pp. 373-396. John Wiley and Sons, New York, NY.

Liu, T.-J., L. Liu, and W.F. Marzluff. 1987. Mouse histone $\mathrm{H} 2 \mathrm{a}$ and $\mathrm{H} 2 \mathrm{~b}$ genes; four functional genes and a pseudogene undergoing gene conversion with a closely linked functional gene. Nucleic Acids Res. 15: 3023-3039.

Liu, T.-J., B.J. Levine, A.I. Skoultchi, and W.F. Marzluff. 


\section{MOUSE HISTONE GENE CLUSTER ON CHROMOSOME 13}

1989. The efficiency of 3 '-end formation contributes to the relative levels of different histone mRNAs. Mol. Cell. Biol. 9: 3499-3508.

Mannironi, C., W.M. Bonner, and C.L. Hatch. 1989. H2A.X. A histone isoprotein with a conserved C-terminal sequence, is encoded by a novel mRNA with both DNA replication type and polyA $3^{\prime}$ processing signals. Nucleic Acids Res. 17: 9113-9126.

Marzluff, W.F. 1992. Histone 3 ' ends: Essential and regulatory functions. Gene Expression 2: 93-97.

Marzluff, W.F., L.A. Sanders, D.M. Miller, and K.S. McCarty. 1972. Two chemically and metabolically distinct forms of calf thymus histone F3. J. Biol. Chem. 247: 2026-2031.

Meier, V.S., R. Böhni, and D. Schümperli. 1989. Nucleotide sequence of two mouse histone H4 genes. Nucleic Acids Res. 17: 795.

Mowry, K.L.and J.A. Steitz. 1987. Identification of the human U7 snRNP as one of several factors involved in the $3^{\prime}$ end maturation of histone premessenger RNA's. Science 238: 1682-1687.

Nagata, T., T. Kato, T. Morita, M. Nozaki, H. Kubota, H. Yagi, and A. Matsushiro. 1991. Polyadenylated and 3' processed mRNAs are transcribed from the mouse histone H2A.X gene. Nucleic Acids Res. 19: 2441-2447.

Nakayama, T., S. Takechi, and Y. Takami. 1993. The chicken histone gene family. Comp. Biochem. Physiol. B Comp. Biochem. 104B: 635-639.

Olson, M.V., K. Loughney, and B.D. Hall. 1979. Identification of the yeast DNA sequences that correspond to specific tyrosine-inserting nonsense suppressor loci. J. Mol. Biol. 132: 387-410.

Parseghian, M.H., A.H. Henschen, K.G. Krieglstein, and B.A. Hamkalo. 1994. A proposal for a coherent mammalian histone $\mathrm{H} 1$ nomenclature correlated with amino acid sequences. Protein Sci. 3: 575-587.

Patthy, L. and E.L. Smith. 1975. Histone III:VI. Two forms of calf thymus histone III. J. Biol. Chem.

250: $919-920$.

Riley, J., D. Ogilvie, R. Finniear, D. Jenner, S. Powell, R. Anand, J.C. Smith, and A.F. Markham. 1990. A novel, rapid method for the isolation of terminal sequences from yeast artificial chromosome (YAC) clones. Nucleic Acids Res. 18: $2887-2890$.

Schwartz, D.C.and C.R. Cantor. 1984. Separation of yeast chromosome-sized DNAs by pulsed-field gradient gel electrophoresis. Cell 37: 67-75.

Sierra, F.A., F. Lichtler, F. Marashi, R. Rickles, T. Van Dyde, S. Clark, J. Wells, G. Stein, and J. Stein. 1982.
Organization of human histone genes. Proc. Natl. Acad. Sci. 79: 1795-1799.

Sittman, D.B., I.-M. Chiu, C.-J. Pan, R.H. Cohn, L.H. Kedes, and W.F. Marzluff. 1981. Isolation of two clusters of mouse histone genes. Proc. Natl. Acad. Sci.

78: $4078-4082$

Sittman, D.B., R.A. Graves, and W.F. Marzluff. 1983a. Histone mRNA concentrations are regulated at the level of transcription and mRNA degradation. Proc. Natl. Acad. Sci. 80: $1849-1853$

1983b. Structure of a cluster of mouse histone genes. Nucleic Acids Res. 11: 6679-6697.

Soldati, D. and D. Schümperli. 1988. Structural and functional characterization of mouse U7 small nuclear RNA active in $3^{\prime}$ processing of histone pre-mRNA. Mol. Cell. Biol. 8: 1518-1524

Stimac, E., V.E. Groppi Jr., and P. Coffino. 1984. Inhibition of protein synthesis stabilizes histone mRNA. Mol. Cell. Biol. 4: 2082-2087.

Taylor, J.D., S.E. Wellman, and W.F. Marzluff. 1986. Sequences of four mouse histone H3 genes: Implications for evolution of mouse histone genes. J. Mol. Evol. 23: 242-249.

Triputti, P., B.S. Emanuel, C.M. Croce, L.G. Green, G.S. Stein, and J.L. Stein. 1986. Human histone genes map to multiple chromosomes. Proc. Natl. Acad. Sci.

83: $3185-3188$

Turner, P.C. and H.R. Woodland. 1983. Histone gene number and organisation in Xenopus: Xenopus borealis has a homogeneous major cluster. Nucleic Acids Res. 11: 971-986.

Wang, Z.-F., R. Tisovec, R.W. Debry, M.R. Frey, A.G. Matera, and W.F. Marzluff. 1996. Characterization of the $55-\mathrm{kb}$ mouse histone gene cluster on chromosome 3. Genome Res. (this issue).

Wells, D. and L. Kedes. 1985. Structure of a human histone cDNA: Evidence that basally expressed histone genes have intervening sequences and encode polyadenylated mRNAs. Proc. Natl. Acad. Sci. 82: $2834-2838$.

Wu, R.S. and W.M. Bonner. 1981. Separation of basal histone synthesis from $S$ phase histone synthesis in dividing cells. Cell 27: 321-330.

Yang, Y.S., D.T. Brown, S.E. Wellman, and D.B. Sittman. 1987. Isolation and characterization of a mouse fully replication-dependent $\mathrm{H} 1$ gene within a genomic cluster of core histone genes. J. Biol. Chem. 262: 17118-17125.

Zweidler A. 1984. Core histone variants of the mouse: Primary structure and expression. In Histone genes: Structure, organization and regulation (ed. G. Stein, W. Stein, and W. Marzluff), pp. 373-395. John Wiley and Sons, New York, NY.

Received March 14, 1996; accepted in revised form June 16, 1996. 


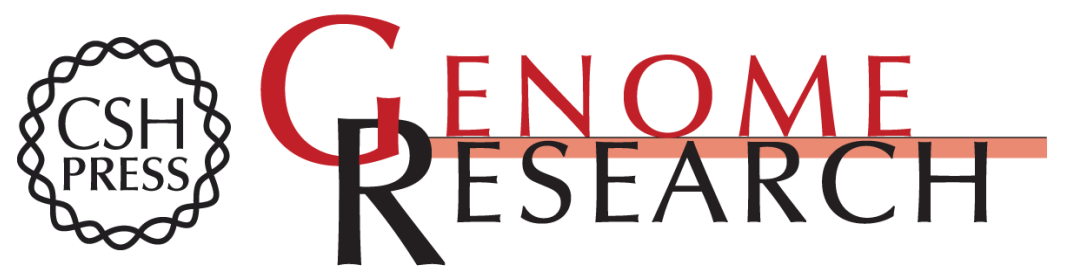

\section{Characterization of the mouse histone gene cluster on chromosome 13: 45 histone genes in three patches spread over $1 \mathrm{Mb}$.}

Z F Wang, T Krasikov, M R Frey, et al.

Genome Res. 1996 6: 688-701

Access the most recent version at doi:10.1101/gr.6.8.688

References This article cites 55 articles, 20 of which can be accessed free at:

http://genome.cshlp.org/content/6/8/688.full.html\#ref-list-1

\section{License}

Email Alerting

Receive free email alerts when new articles cite this article - sign up in the box at the Service top right corner of the article or click here.

\section{Affordable, Accurate Sequencing.}

To subscribe to Genome Research go to: https://genome.cshlp.org/subscriptions 